\title{
Re-evaluation of the macroseismic effects produced by the March 4, 1977, strong Vrancea earthquake in Romanian territory
}

\author{
Aurelian Pantea, Angela Petruta Constantin ${ }^{\star}$
}

National Institute for Earth Physics (NIEP), Bucharest-Magurele, Romania

\author{
Article history \\ Received March 7, 2012; accepted October 10, 2012. \\ Subject classification: \\ Historical seismology, Seismic risk, Seismological data, Earthquake source and dynamics, Environmental risk.
}

\begin{abstract}
In this paper, the macroseismic effects of the subcrustal earthquake in Vrancea (Romania) that occurred on March 4, 1977, have been re-evaluated. This was the second strongest seismic event that occurred in this area during the twentieth century, following the event that happened on November 10, 1940. It is thus of importance for our understanding of the seismicity of the Vrancea zone. The earthquake was felt over a large area, which included the territories of the neighboring states, and it produced major damage. Due to its effects, macroseismic studies were developed by Romanian researchers soon after its occurrence, with foreign scientists also involved, such as Medvedev, the founder of the Medvedev-SponheuerKarnik (MSK) seismic intensity scale. The original macroseismic questionnaires were re-examined, to take into account the recommendations for intensity assessments according to the MSK-64 macroseismic scale used in Romania. After the re-evaluation of the macroseismic field of this earthquake, the intensity dataset was obtained for 1,620 sites in Romanian territory. The re-evaluation was necessary as it has confirmed that the previous macroseismic map was underestimated. On this new map, only the intensity data points are plotted, without tracing the isoseismals.
\end{abstract}

\section{Introduction}

Nowadays, great attention is given to re-evaluation studies of macroseismic information associated to earthquakes that occurred in the pre-instrumental and instrumental eras. Here, these studies imply reinterpretation of the macroseismic effects produced mainly by major subcrustal earthquakes that occurred in Romanian territory. Macroseismic data are used to complete the picture of the spatial distribution of the seismic intensity for the purpose of hazard assessment for areas or sites for construction of the national infrastructure [Moldovan et al. 2008].

The purpose of this paper was to re-evaluate the macroseismic effects of the subcrustal Vrancea earthquake that occurred during the evening of March 4, 1977. This earthquake was one of the strongest that has occurred in Romania, with the epicenter in the south-eastern Carpathian bend, a region known as the Vrancea seismogenic zone. In this region, two types of earthquakes occur: intracrustal earthquakes (less than $60-70 \mathrm{~km}$ deep), and subcrustal earthquakes (between 70 and $200 \mathrm{~km}$ deep). The seismicity of Romania from 984 to 2011 for shocks with magnitude $\mathrm{M}_{\mathrm{W}} \geq 3$ is shown in Figure 1 [Romplus catalog 2011]. The distribution of the epicenters for the Vrancea earthquakes from the same period is shown in Figure 2. The earthquakes that have occurred in the Vrancea seismic zone are responsible for $90 \%$ of the seismic activity in Romania, thus releasing more than $95 \%$ of the total seismic energy. Therefore, the seismicity of the Romanian territory and its specific pattern is strongly determined by the Vrancea seismogenic zone. This region is characterized by strong subcrustal earthquakes $\left(\mathrm{M}_{\mathrm{W}}>7.0\right)$, the frequency of occurrence of which is low (4-5 destructive earthquakes per century). The crustal seismicity of this region is characterized by moderate earthquakes with magnitudes that have not exceeded $\mathrm{M}_{\mathrm{W}} 5.9$, with this value being assigned to an earthquake that occurred in historical times on March 1, 1894 [Oncescu et al. 2000, Romplus catalog 2011]. The last earthquake that occurred in this region was the October 27, 2004, subcrustal earthquake [Romplus catalog 2011], which was the only significant event over the last two decades, both in terms of magnitude $\left(\mathrm{M}_{\mathrm{W}} 6\right)$ and observed macroseismic effects.

\section{The March 4, 1977, Vrancea earthquake}

The March 4, 1977, seismic event had a magnitude MW of 7.4 and occurred at 19:21 hours GMT (21:21 local time); it is considered as one of the most violent earthquakes to hit Romania. The epicentral intensity was assigned at $\mathrm{I}_{0}$ VIII on the Medvedev-Sponheuer-Karnik (MSK) seismic intensity scale [Radu et al. 1979a]. Seismological studies established the multi-shock character of this earthquake, as at least three shocks, with $14 \mathrm{~s}$ between the first and the last shock [Müller et al. 1978]. The epicenters were located in the south-eastern Carpathian bend: $\mathrm{S} 1\left(45.72{ }^{\circ} \mathrm{N}, 26.94{ }^{\circ} \mathrm{E}\right.$; depth, $\left.79 \mathrm{~km}\right), \mathrm{S} 2$ $\left(45.48{ }^{\circ} \mathrm{N}, 26.78^{\circ} \mathrm{E}\right.$; depth, $\left.93 \mathrm{~km}\right)$ and $\mathrm{S} 3\left(45.34^{\circ} \mathrm{N}, 26.30^{\circ} \mathrm{E}\right.$; 


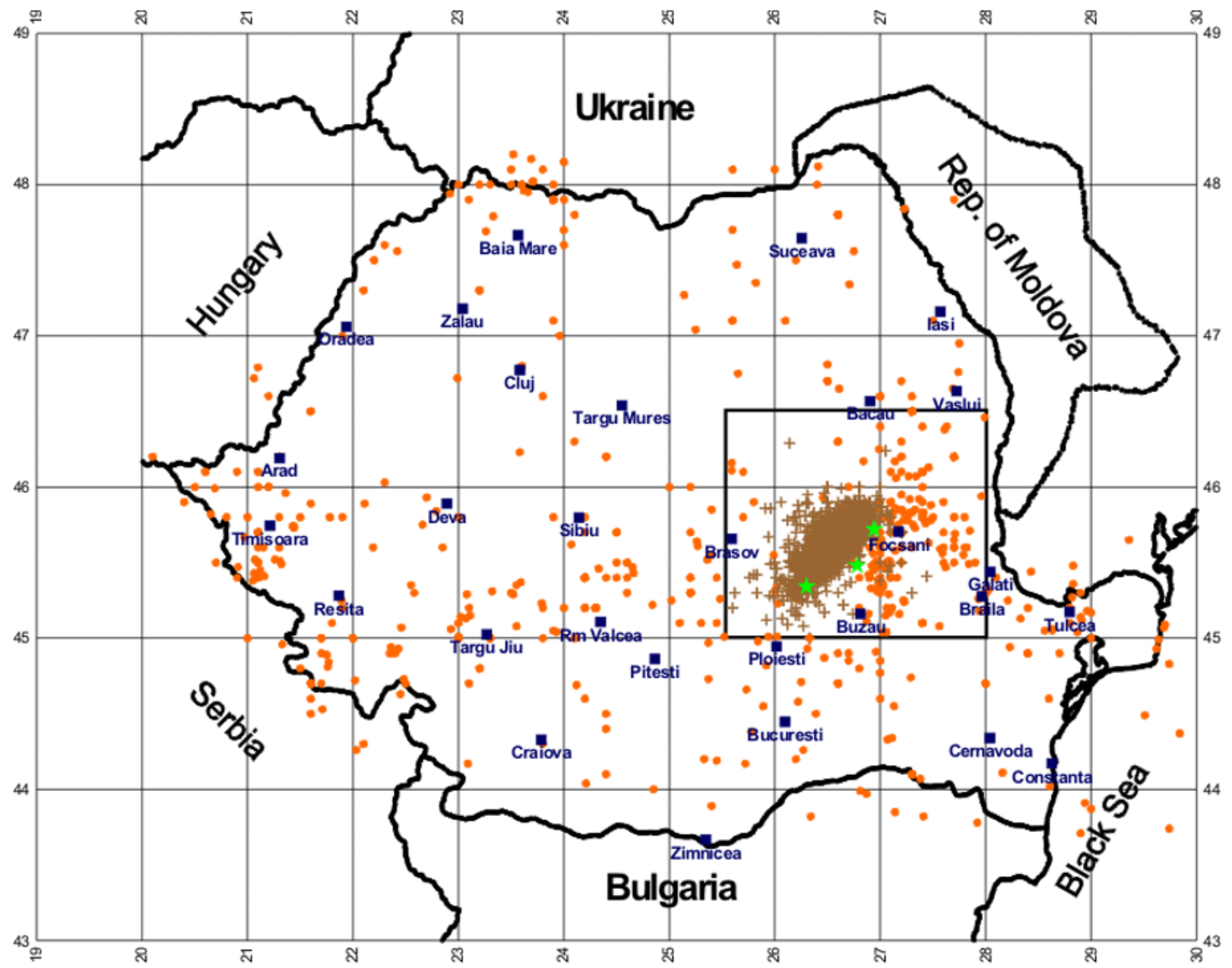

Figure 1 (above). Seismicity of Romania from 984 to 2011, for $M_{W} \geq 3$. Brown crosses, subcrustal earthquakes; orange dots, crustal earthquakes [from Romplus catalog 2011].

Figure 2 (below). Seismicity of the Vrancea zone. The stars correspond to the epicenters of the three shocks of 1977. The area corresponds to that indicated in Figure 1.

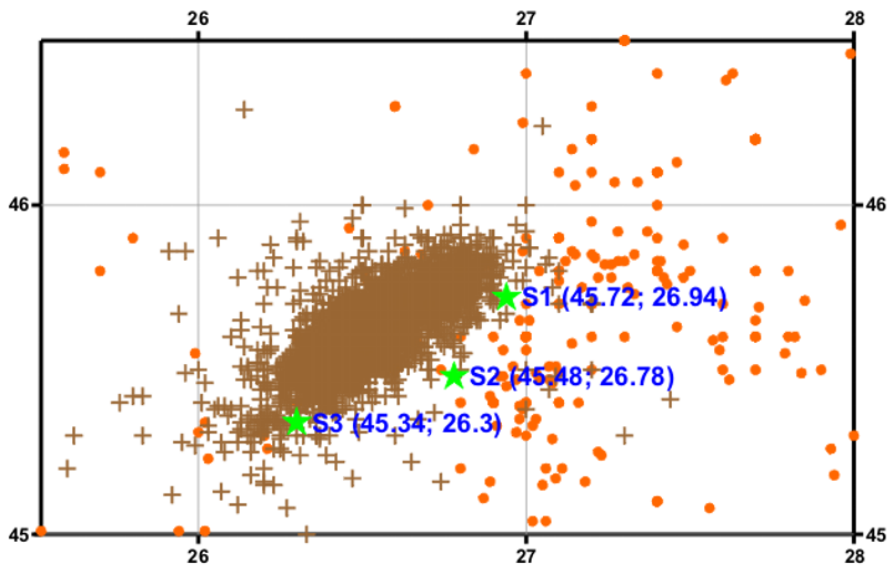

depth, $109 \mathrm{~km}$ ) (Figure 2), thus emphasizing that the rupture focus propagated to the SSW [Müller et al. 1978].

The multi-shock character of this earthquake emphasized the complexity of the Vrancea seismogenic zone tectonics, which has thus attracted the interest of the international scientific community. This multi-shock event was followed by 146 aftershocks with foci at depths $\geq 60 \mathrm{~km}$.
The first aftershock had a magnitude $\mathrm{M}_{\mathrm{W}}$ of 4.3 , and it occurred $4.6 \mathrm{~h}$ after the main shock. The main shock was also preceded by an earthquake of magnitude $\mathrm{M}_{\mathrm{GR}} 5.5$ (the Gutenberg-Richter magnitude, as introduced by Gutenberg and Richter [1954]).

This March 4, 1977, earthquake represents the greatest tragedy in the past 30 years in Romania, and it resulted in major human and property losses. The greatest damage was concentrated in the southern part of Romania, particularly in urban centers with high densities of population and constructions. This was especially seen in cities such as Bucharest, Craiova, Zimnicea, Turnu and Magurele, as well as in many towns and villages; e.g., Darasti (Ilfov county), Adunatii Copaceni (Giurgiu county), among others. The Romanian counties and some of the localities affected by this earthquake and mentioned in this paper are shown in Figure 3. The earthquake caused the death of 1,578 people, of which 1,424 were recorded for Bucharest alone. Over 10,000 people were found under the collapsed buildings in the capital, while across the entire country, about 11,300 people were injured and about 35,000 buildings were severely damaged or destroyed. The majority of the damage was concentrated in Bucharest, where more than 33 buildings collapsed. The town of Zimnicea was almost totally destroyed, with many people found dead under the ruins. Major damage was reported in the town of Craiova and in the neighboring 


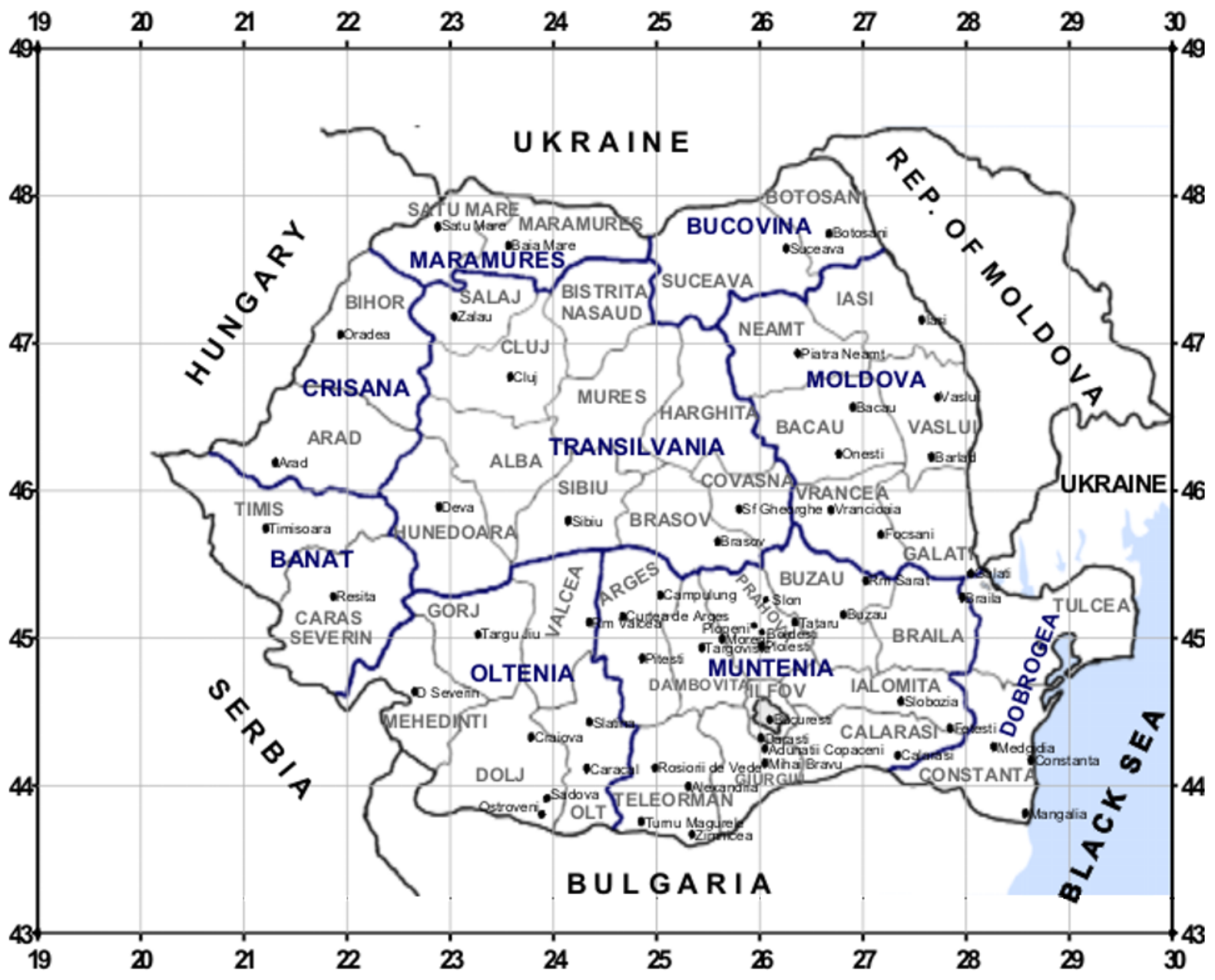

Figure 3. Romanian regions: counties and places mentioned in the text and in Table 1.

areas, such that in less than $60 \mathrm{~s}$, a great part of the old building stock was severely damaged, with the collapse of 537 buildings and the death of 41 people, as well as 812 people injured [Trita et al. 1978]. In Prahova county, the effects were also significant, with partial or total damage to some civil and religious buildings (see Figures 4, 5). The total loss estimated at the time exceeded two billion US dollars, of which 1.4 billion US dollars was indicated for Bucharest alone.

This earthquake was felt in the north of Finland and in central Greece. To the east, it was felt up to the western edge of the Caucasus Mountains, and to the west, to Germany. Moreover, as well as the European countries, the shock was felt in Asia, in Lebanon, and even on the African continent, in Egypt [Radu et al. 1979b]. The maximum macroseismic effects in the Bulgarian territory were estimated at VIII MSK and were reported along the Danube and in the northeastern areas, with the minimum effects reaching to III-IV MSK in the south of Bulgaria [Grigorova et al. 1977].

Thus, for this earthquake, the National Earthquake Information Center (NEIC) reported the following: ca. 1,500 people dead, 10,500 people injured, and major damage to Bucharest and in other parts of Romania. Bulgaria reported 20 people dead and 165 people injured. Some injuries and damage were reported in Yugoslavia. This earthquake was felt from Rome to Moscow, and from Turkey to Finland (http:/ / earthquake.usgs.gov/earthquakes/world/world_deaths.php).

\section{Macroseismic data}

The macroseismic effects produced by an earthquake on the Earth surface represent the set of observational data that is necessary to assess the seismic intensities. Macroseismic intensity assessment implies laborious and extensive activities, which usually involve the performing of two combined and separate investigations: macroseismic questionnaires and direct field surveys [e.g., De Rubeis et al. 1992, Grünthal 1998, Musson and Cecić 2002, Cecić and Musson 2004, Mäntyniemi 2004]. Field reports are prepared by teams that consist of seismologists, geophysicists, geologists and civil engineers, and the purpose is to inventory, interpret and assess the macroseismic effects generated by the seismic shaking in the damaged areas.

During this 1977 earthquake, the Romanian seismic stations broke down, except for the SMAC-B accelerometer that was installed at the URBAN-INCERC station in the Pantelimon district (Bucharest). Great attention was then focussed on the macroseismic investigation of the effects produced in the Romanian territory.

To determine the seismic intensities immediately after 

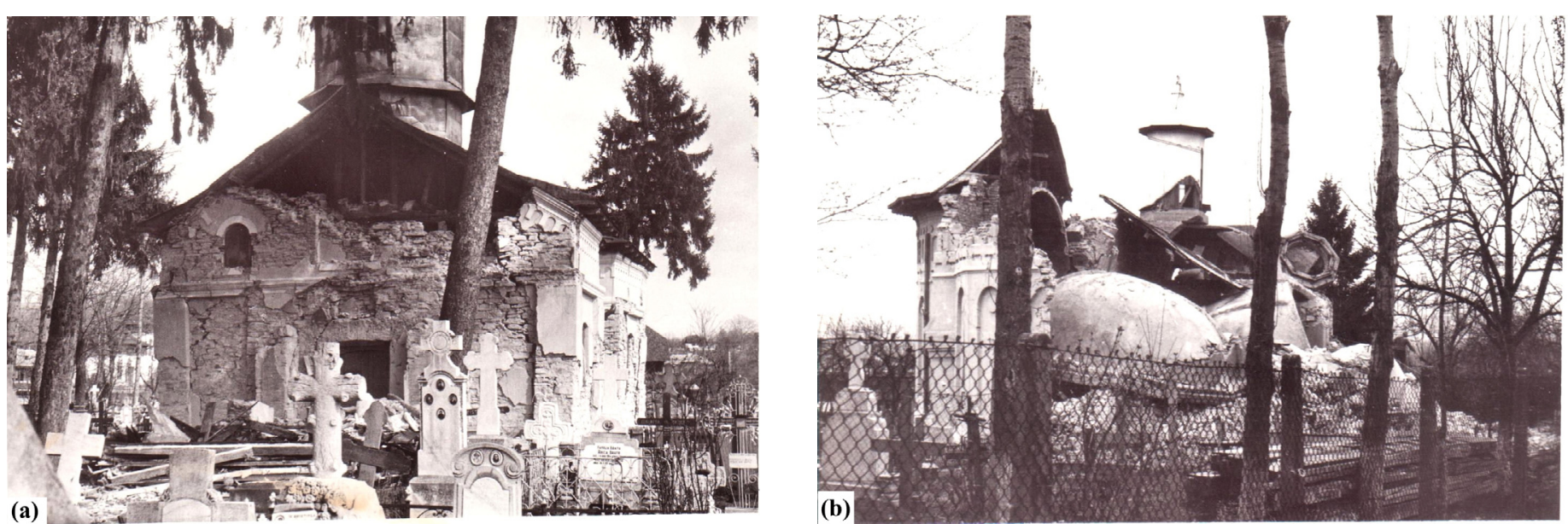

Figure 4. Masonry buildings destoyed in Prahova county. (a) Partial collapse of a church in Drajna (subsequently demolished). (b) Total collapse of a church in Boldesti (photos by Pantea [1979]).

the earthquake, more than 12,000 macroseismic questionnaires were distributed in areas throughout the country, and especially in the damaged areas of Oltenia, Muntenia and Moldova (see Figure 3), among others, to obtain a more complete and unitary image of the macroseismic effects. The macroseismic questionnaires were distributed to the local/ public authorities, and directed to the population. They needed to be filled in and then sent to the Centre for Earth Physics and Seismology (now the National Institute for Earth Physics, Bucharest-Magurele, Romania). The macroseismic questionnaire used for this earthquake contained a number of questions related to construction types, nature and degree of damage, effects on the surroundings, and human and animal reactions. The first part of this macroseismic questionnaire included the administrative data (e.g., locality, owner, street), the types of buildings (i.e., A, B, C structures), and the classification of the damage to buildings (all 5 grades), according to the MSK-64 macroseismic scale [Medvedev et al. 1967]. Each observer thus had the possibility to select the type of building and the level of damage caused by the earthquake to the building in question. The other questions were related to effects felt by the people, and the effects on objects and on the environment, as 54 questions, and they covered

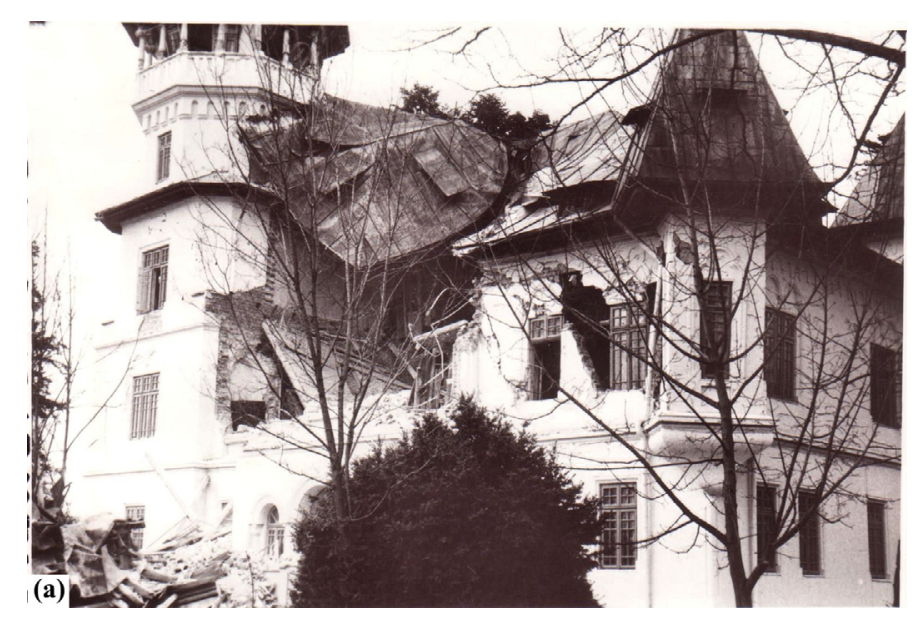

the intensity degrees from II to X of the MSK-64 macroseismic scale. Nine questions referred to the environmental effects, which have also been used in the intensity assessment. However, in this type of questionnaire, the set of questions follows the effects reported for the MSK-64 macroseismic scale, and it also includes some additional questions that are not mentioned in the scale; these were useful to have a more complete description of the earthquake effects. The last question of the macroseismic questionnaire referred to other peculiar effects that were observed (acoustic and lighting effects were usually reported here by the observers).

Also, in the days following the earthquake, specialists from the Centre for Earth Physics and Seismology and from the Institute of Geology and Geophysics went to the Vrancea region and to other regions in Romania to collect data on the macroseismic effects observed in the field [Pantea et al. 1977, Pantea 1979, Mandrescu 1979].

As with macroseismic questionnaires, the field surveys consisted of carrying out an inventory and assessments of the macroseismic effects produced by the earthquake, and they were focused mainly on the following patterns:

a. Effects on structures;

b. Human and animal reactions through all three phases:

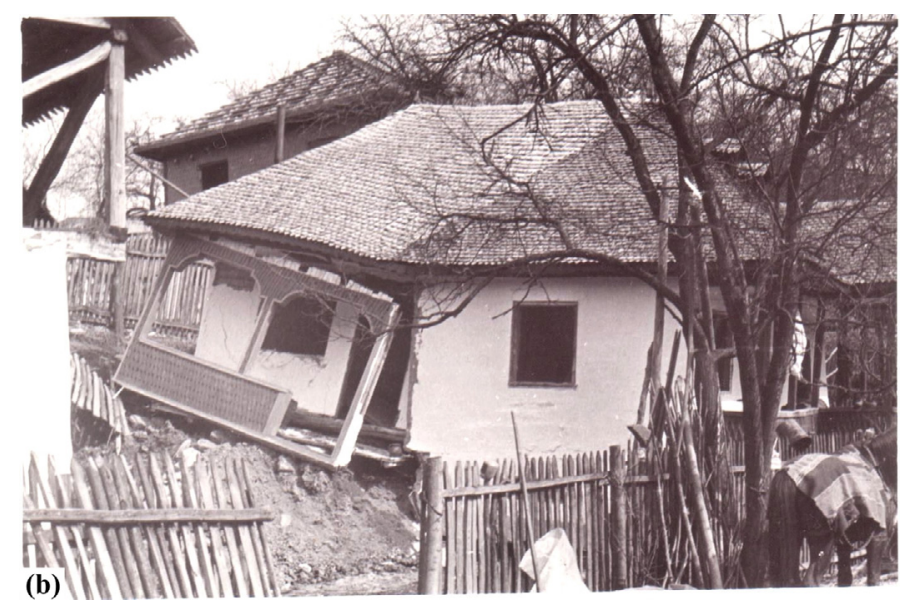

Figure 5. Partial collapse of a masonry building at Drajna (a) and heavy damage to a wooden house at Slon (b), in Prahova county (photos by Pantea [1979]). 


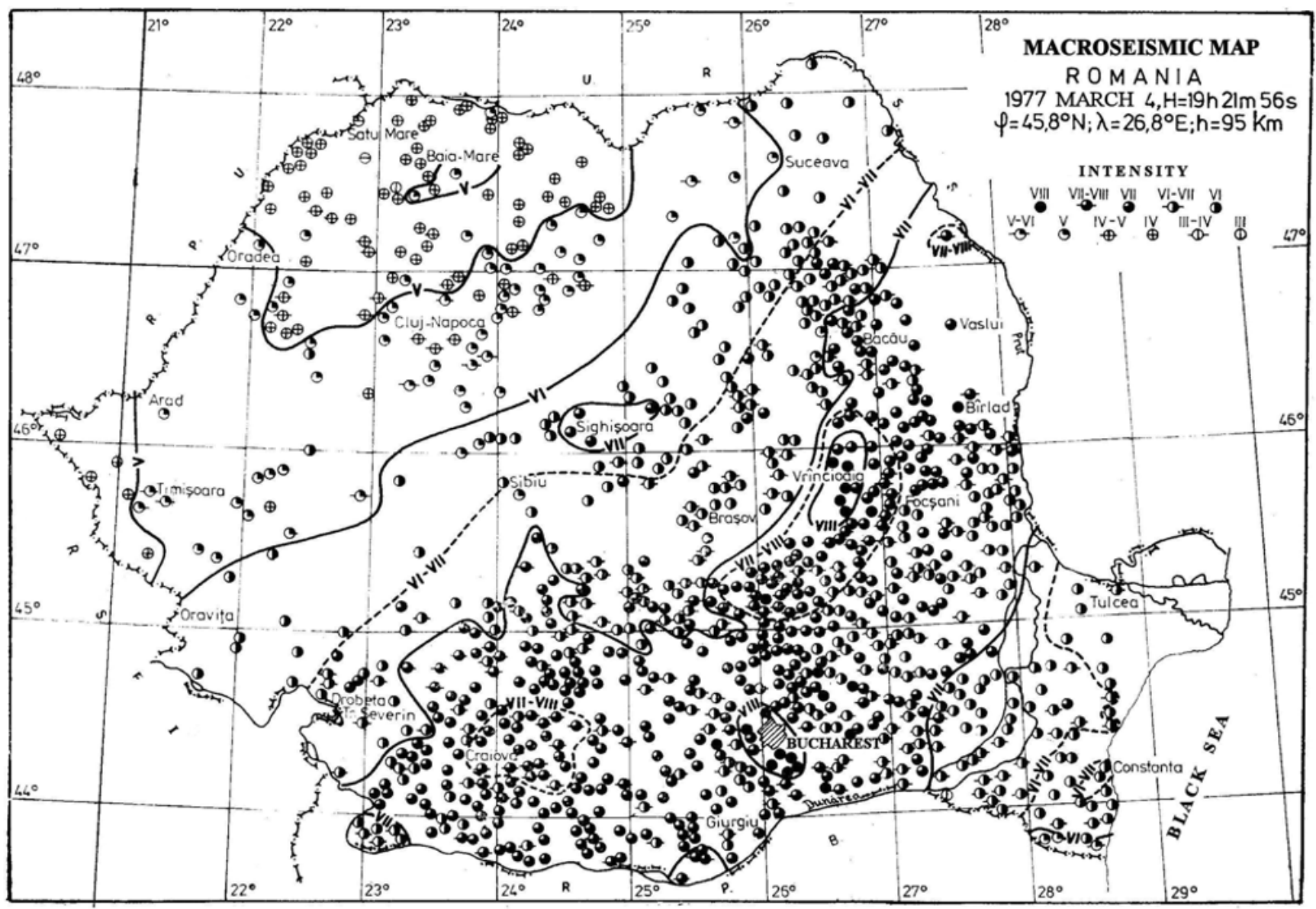

Figure 6. Macroseismic map for the March 4, 1977, Vrancea earthquake, as drawn up by Radu et al. [1979a].

pre-seismic, co-seismic, and post-seismic;

c. Effects on the environment.

During the survey, one of the authors of the present report visited some of the areas damaged by the earthquake, including Prahova, Dambovita and Arges counties (central part of Romania), to make in-situ assessments of the intensities. In the built-up areas in these counties, the constructions damaged by this event were mainly investigated. The field visit helped in the assessment of both the vulnerability classes of the buildings and the grades of damage in the towns and villages in these counties. For example, at Slon and Boldesti, both of which are towns situated in Prahova county, the damage to the building stock reached the level of 5 degrees, according to the MSK scale. These two towns are located approximately $30 \mathrm{~km}$ and $50 \mathrm{~km}$, respectively, from the epicenter of the last of the shocks (S3) of this March 4, 1977, earthquake. Also, many landslides occurred in these areas; at Slon, there was a landslide in the southern part of the Izvorul Negru and the eastern part of the Drajnutei valley. Here, 22 houses located on the slope were destroyed by the debris from the landslide. Figure $5 \mathrm{~b}$ shows an example of a wooden house that was heavily damaged in the village of Slon. Vertical and horizontal cracks and fissures were observed on a bridge in the town of Plopeni (Prahova county), with ca. $10 \mathrm{~cm}$ displacement of the concrete bridge over the Cosmina River.

In Ploiesti county hospital, the B block was displaced from the north to the south, and the walls of the hospital were crossed by large diagonal cracks, with a drop of the portions of the wall material.

Many churches in the areas visited were heavily affected, with wide and deep cracks in walls, and partial or total collapse (see Figure 4). Some industrial constructions, hospitals and schools in the towns in these counties were seriously damaged as a result of the earthquake.

On the basis of the macroseismic data collected after the earthquake, Romanian researchers drew up an isoseismal map, with several versions, which were generally constructed by the same researchers [Radu et al. 1979a, Radu and Polonic 1982] (see Figure 6). In the last version of the macroseismic map drawn up by Radu and Utale [1989], the seismic intensity was defined in integer numbers. The macroseismic studies on this March 4, 1977, earthquake were performed simultaneously by the Romanian researchers and by some foreign scientists, such as Shebalin and Kárník, and the academician Medvedev, the founder of the MSK seismic scale. Indeed, immediately after this earthquake occurred, and despite his old age, Medvedev went to Bucharest, accompanied by a delegation of seismologists. Medvedev, who knew the scientific and practical importance of macroseismic maps for the seismic design of buildings, visited some of the damaged areas, to inventory and evaluate these effects, knowing that traces of a disaster are rapidly removed, to nor- 


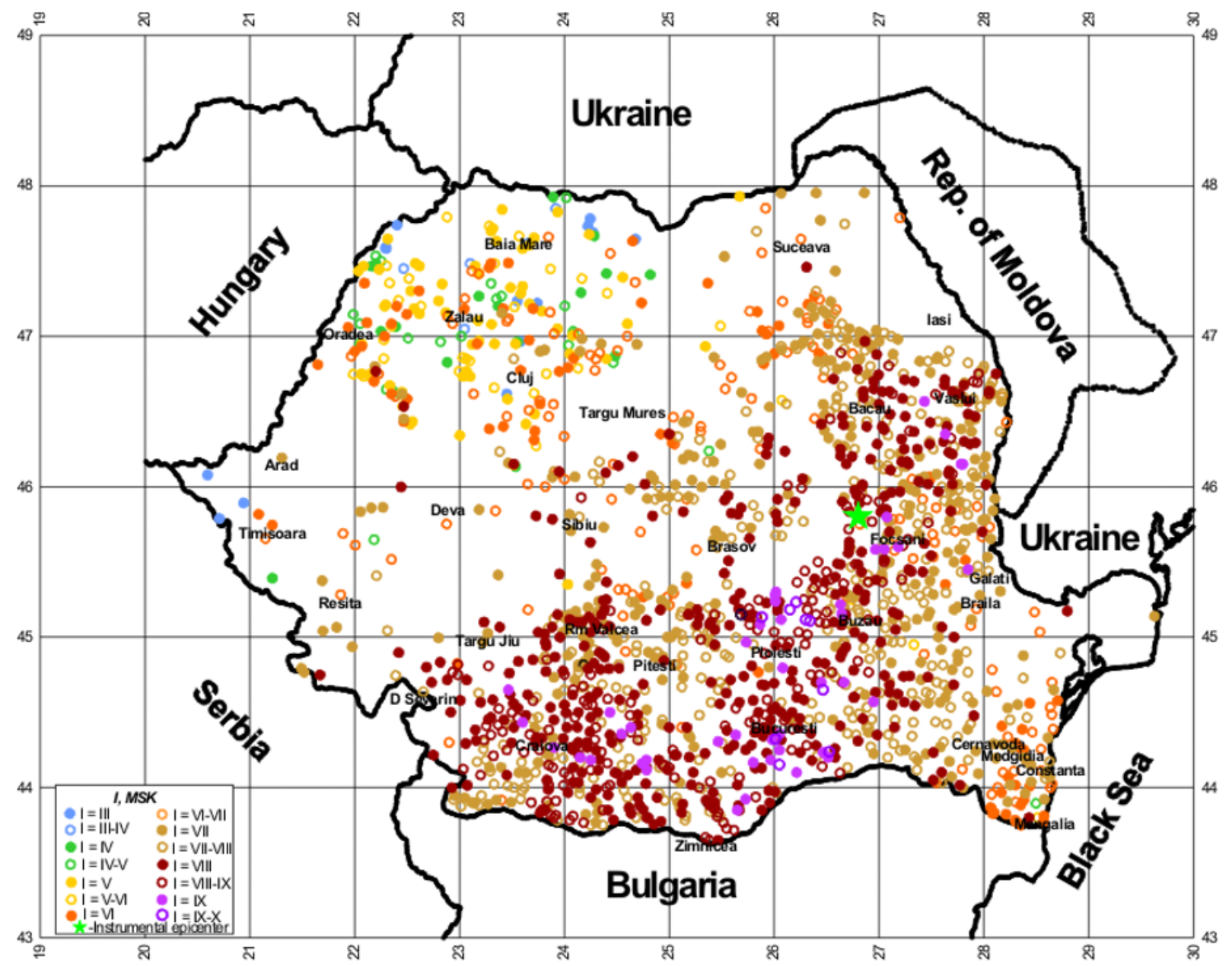

Figure 7. Re-evaluated macroseismic map of the March 4, 1977, subcrustal earthquake.

malize life in affected areas. As this earthquake was felt over a large area, the macroseismic studies were also carried out in other countries that experienced the shaking: Bulgaria, Serbia (Yugoslavia), the Republic of Moldova and Russia (USSR), Greece, Austria, Slovakia (Czechoslovakia), Germany (GDR), Hungary, and Poland [Radu et al. 1979b].

\section{Re-evaluated macroseismic map}

The re-evaluation of the macroseismic effects associated with this major earthquake that occurred on March 4, 1977, was carried out to remove some of the inherent uncertainties in the processing, interpretation and assessment of the observational data.

To assign the seismic intensities, a re-evaluation was performed of the information contained in the 12,125 macroseismic questionnaires that were collected in Romania immediately after the March 4, 1977, earthquake, and also in those from Bucharest (1,925 forms). We estimated the intensities for each site using the MSK-64 macroseismic scale. We decided to re-evaluate the intensities in the MSK intensity scale for a number of reasons: (a) to compare our values with those formerly assigned and published by Radu et al. [1979a]; (b) to ensure the homogeneity with the Romanian database; and (c) the MSK scale is still used in Romania. In the process of this re-evaluation, our attention was focused on the earthquake effects on buildings, thus providing intensity assessments of a more 'objective' nature, knowing that estimates made mainly based on human perception (human reactions and effects on objects) are considered to have a greater degree of subjectivity. Thus, the re-evaluated macroseismic intensities were obtained for 1,620 sites, as in some of the questionnaires it was reported that at some sites in the northwestern part of the Romanian territory the earthquake was not felt. For Iasi county (northeastern part of Romania), the macroseismic intensity could not be plotted because the macroseismic questionnaires are unfortunately missing from the Institute archive. All of these reassessments were used to organize a new database with intensity data points of the March 4, 1997, earthquake from across the Romanian territory.

The distribution of the re-evaluated macroseismic intensities observed for the Romanian territory is shown in Figure 7. Table 1 gives the re-evaluated macroseismic intensities for some of the most important cities in Romania, together with the total number of macroseismic questionnaires that were available for each city, and the epicentral distances. All of the cities in Table 1 are shown in Figure 3.

The maximum observed intensity was IX-X MSK, which was assigned to several sites, such as Tataru (Prahova county) 


\begin{tabular}{|c|c|c|c|c|c|c|}
\hline No. & County & Town/ city & $\begin{array}{l}\text { No. of macroseismic } \\
\text { questionnaires }\end{array}$ & $\begin{array}{c}\text { I (MSK) } \\
\text { (present study) }\end{array}$ & $\begin{array}{c}\text { I (MSK) } \\
\text { [Radu et al. 1979a] }\end{array}$ & $\Delta(\mathbf{k m})$ \\
\hline 1 & Arad & Arad & 11 & VII & V & 428 \\
\hline 2 & Arges & Pitesti & 161 & VII & VII & 184 \\
\hline 3 & Arges & Curtea de Arges & 61 & VII & VI-VII & 181 \\
\hline 4 & Arges & Campulung & 53 & VI-VII & VI-VII & 148 \\
\hline 5 & Bacau & Onesti & 36 & VII-VIII & VII & 50 \\
\hline 6 & Bihor & Oradea & 10 & VI & $\mathrm{V}$ & 399 \\
\hline 7 & Botosani & Botosani & 7 & VII-VIII & VI & 216 \\
\hline 8 & Braila & Braila & 11 & VII & VI-VII & 108 \\
\hline 9 & Brasov & Brasov & 15 & VII-VIII & VI-VII & 95 \\
\hline 10 & Buzau & Ramnicu-Sarat & 22 & VII & VII & 49 \\
\hline 11 & Buzau & Buzau & 35 & VII-VIII & VII & 71 \\
\hline 12 & Cluj & Cluj Napoca & 11 & VI & V & 270 \\
\hline 13 & Constanta & Constanta & 88 & VII-VIII & VI-VII & 231 \\
\hline 14 & Covasna & Sfantu Gheorghe & 12 & VII-VIII & VI-VII & 78 \\
\hline 15 & Dambovita & Targoviste & 90 & VII-VIII & VII & 143 \\
\hline 16 & Dambovita & Moreni & 50 & VII-VIII & VII & 127 \\
\hline 17 & Dolj & Craiova & 88 & VIII & VIII & 288 \\
\hline 18 & Dolj & Ostroveni & 9 & VIII-IX & VII-VIII & 320 \\
\hline 19 & Dolj & Sadova & 6 & VIII-IX & VII-VIII & 309 \\
\hline 20 & Galati & Galati & 95 & VII-VIII & VI-VII & 105 \\
\hline 21 & Giurgiu & Adunatii Copaceni & 6 & IX & VIII & 178 \\
\hline 22 & Giurgiu & Calugareni & 5 & IX & VIII & 192 \\
\hline 23 & Gorj & Targu Jiu & 13 & VII & VII & 289 \\
\hline 24 & Ialomita & Slobozia & 78 & VII-VIII & VII & 144 \\
\hline 25 & Ialomita & Fetesti & 50 & VII & VI-VII & 177 \\
\hline 26 & Ilfov & Darasti & 28 & IX-X & VIII & 171 \\
\hline 27 & Calarasi & Calarasi & 92 & VII-VIII & VII & 182 \\
\hline 28 & Maramures & Baia Mare & 14 & V-VI & $\mathrm{V}$ & 322 \\
\hline 29 & Neamt & Piatra Neamt & 22 & VI-VII & VI & 130 \\
\hline 30 & Olt & Slatina & 63 & VII-VIII & VII & 245 \\
\hline 31 & Olt & Caracal & 51 & VIII & VII & 270 \\
\hline 32 & Prahova & Ploiesti & 130 & VIII & VII & 113 \\
\hline 33 & Prahova & Tataru & 6 & IX-X & VIII & 81 \\
\hline 34 & Satu Mare & Satu Mare & 6 & V-VI & IV & 372 \\
\hline 35 & Sibiu & Sibiu & 6 & VII-VIII & VI & 206 \\
\hline 36 & Suceava & Suceava & 6 & VI-VII & VI & 209 \\
\hline 37 & Teleorman & Zimnicea & 140 & VIII-IX & VIII & 263 \\
\hline 38 & Teleorman & Turnu Magurele & 137 & VIII & VII-VIII & 274 \\
\hline 39 & Teleorman & Rosiorii de Vede & 113 & VIII & VII & 235 \\
\hline 40 & Teleorman & Alexandria & 138 & VII-VIII & VII & 232 \\
\hline 41 & Timis & Timisoara & 10 & VI & V & 434 \\
\hline 42 & Vaslui & Barlad & 16 & VIII & VIII & 72 \\
\hline 43 & Vrancea & Vrancioaia & 22 & VIII-IX & VIII & 11 \\
\hline 44 & Vrancea & Focsani & 99 & VII & VII-VIII & 31 \\
\hline 45 & Bucharest & Bucharest & 1,925 & VIII-IX & VIII & 160 \\
\hline
\end{tabular}

Table 1. Seismic intensities arising from the March 4, 1977, earthquake, for the important cities in Romania, and for some sites that suffered the greater damage. $\Delta(\mathrm{km})$, distance from epicenter. 
(all of the six macroseismic questionnaires filled in for this village contain details of macroseismic effects that correspond to an intensity of IX-X MSK) and Darasti (Ilfov county). In the settlement of Tataru, which is located $81 \mathrm{~km}$ southwest from the epicenter, the earthquake caused severe damage. The settlement of Tataru was built mainly of onestorey brick and wooden buildings. Many cases of partial or complete destruction of the houses were reported, along with the collapse of the inner walls. According to the macroseismic questionnaires filled in for this site, the roads were also destroyed during the earthquake; the observers reported that the road paving and the asphalt were cracked and showed waves. Also, the falling of the statues in churches, and tombstones and crosses in cemeteries, were reported.

In the commune of Darasti, this earthquake manifested the same intensity as in the settlement of Tataru, although the distance from the epicenter was greater $(171 \mathrm{~km}$ southwest). The buildings of Darasti (Ilfov county) were generally small housing units with one storey. In this area, buildings from class B were the most numerous. Grades of damage that vary from grade 3 (heavy damage) to grade 5 (total damage), were assigned to the building stock according to the damage description of the MSK-64 scale. In general, a lot of the buildings from class B (brick buildings) suffered grade 5 damage (total or near total collapse). Also, in many masonry houses (type B), there were gaps in the walls, and the collapse of parts of the buildings and of the inner walls (grade 4 damage). In this area, damage to the roads and waves in the road paving and asphalt were reported.

In other heavily damaged sites, such as Adunatii Copaceni (Giurgiu county), the building stock was greatly affected by this earthquake. There were many ordinary brick houses in this area that suffered very heavy damage or partial collapse. Also, some damage occurred to the roads; e.g., cracks and waves in the pavements. Based on these effects, at Adunatii Copaceni the intensity was estimated at IX MSK.

Another commune that was seriously affected by the earthquake was Calugareni (I-IX MSK), which is situated in Giurgiu county. Many buildings of type A (adobe dwellings) suffered grade 5 damage. A few houses of type B suffered the same grade of damage (collapse).

In Sadova and Ostroveni (Dolj county), which are situated in the alluvial plains of the Jiu and Danube rivers at about $309 \mathrm{~km}$ and $320 \mathrm{~km}$ southwest, respectively, from the epicenter, the earthquake caused serious damage to the local houses. These buildings suffered various degrees of damage, from grade 3 to grade 5. At Sadova, many chimneys fell down and a few brick houses were partial destroyed. Also, at Ostroveni, most of the houses were seriously damaged, with a few masonry houses completely destroyed, and many chimneys fell down. We estimated the intensity at both of these towns as between VIII and IX MSK.

Most of the churches in all of the above-mentioned areas were damaged. Many churches suffered serious damage, such as heavy damage to the domes and wide cracks in the walls. These are only a few of the sites where the earthquake produced very heavy damage.

After the re-evaluation of the earthquake effects, an abnormal distribution of intensities was observed through the appearance of higher intensities in areas at hundreds of kilometers from the epicenters. For instance, in Bucharest (IVIII/IX MSK) and Ilfov county (IX-X MSK), and also in Craiova (I-VIII MSK), Zimnicea (I-VIII/IX MSK), Alexandria (I-VII/VIII MSK) (see Table 1). These anomalies can be explained by the influence of the soil conditions (with some alluvial deposits in these areas). These anomalous intensities were also seen in the previous map [Radu et al. 1979a], although the values were different.

As suggested in a study by Ambraseys and Adams [1998] regarding the review of the strong earthquake of June 26, 1926, in the Hellenic Arc, the maximum damage, and therefore the highest intensities, was associated more with sites that are situated on alluvial deposits than with their proximity to the epicenter. This is a typical effect of the long duration of shaking in the near and far fields of large intermediate-depth earthquakes. This situation appears to have occurred in the case of the 1977 earthquake.

The re-evaluated macroseismic map shows for some sites values of seismic intensity that are higher by half to one and a half degrees, compared to those obtained by Radu et al. [1979a] (Figure 6).

In the macroseismic map of the March 4, 1977, earthquake drawn up by Radu et al. [1979a], the seismic intensity in the epicentral area showed an $\mathrm{I}_{0}$ of VIII MSK; after the reevaluation of the macroseismic effects observed in this area, it was concluded that the epicentral intensity was an $\mathrm{I}_{0}$ of IX MSK. Moreover, by comparing the two maps, as the map formerly published and the map from our recent re-evaluation, it can be seen that the areas corresponding to intensity VII and VIII MSK are more extended than those defined in the map drawn by Radu et al. [1979a]; furthermore, in the former map, there were no areas with an intensity of IX MSK.

As can be seen in the re-evaluated macroseismic map (Figure 7), and on the basis of the maximum effects in Bulgarian territory corresponding to VIII MSK [Grigorova et al. 1977], the intensity attenuation was relatively weak in the southwest direction from the epicenter, as had been seen for some previous subcrustal earthquakes with foci in the same area (e.g., the October 26, 1802, earthquake). Thus, the new intensity data-point map presented in Figure 7 accurately reproduces the two main features of the earthquake: the affected area as more extended, and the weak southwestern attenuation. These features were also emphasized in the macroseismic map drawn up by Radu et al. [1979a], but as mentioned above, the values given to the intensities were lower. 


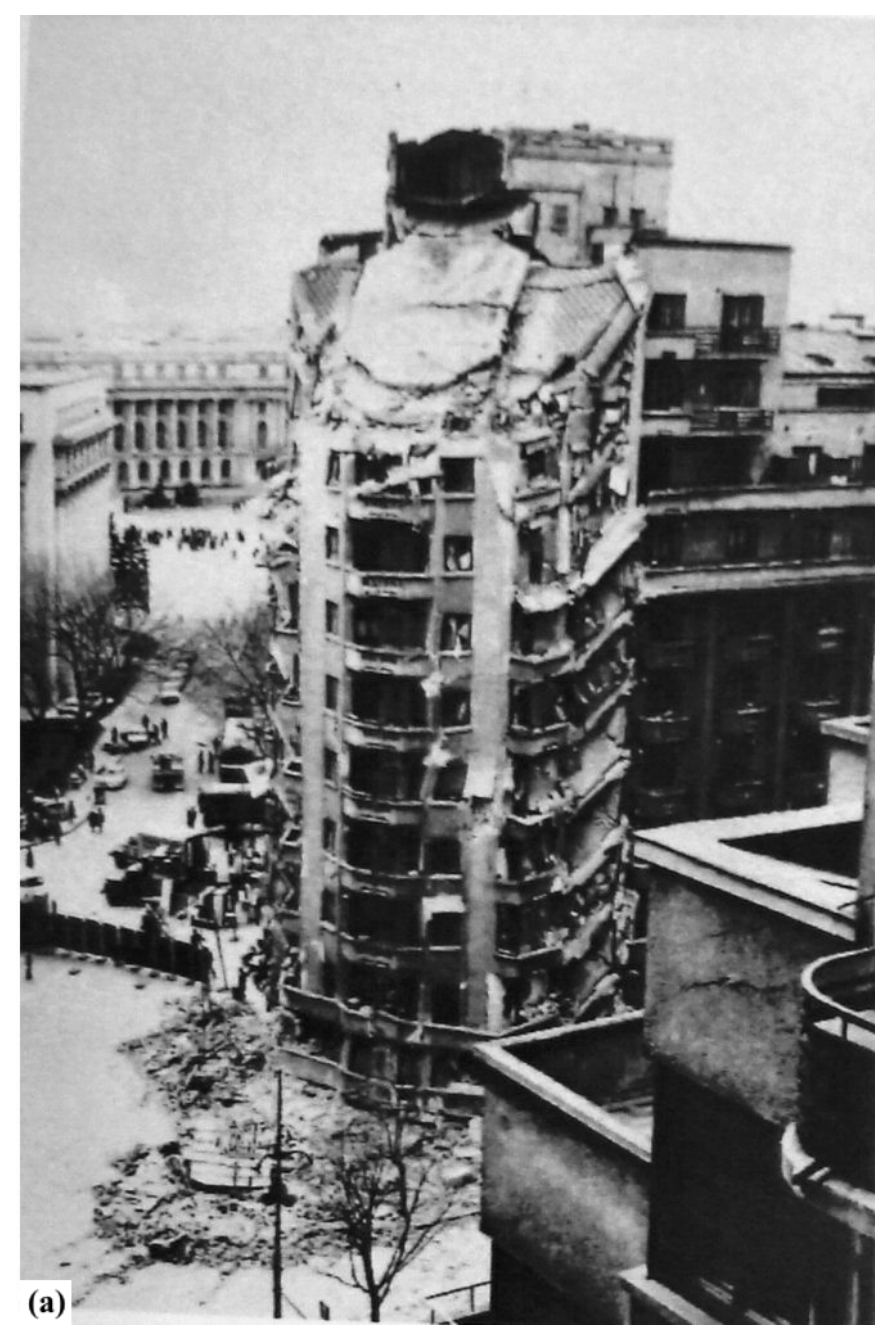

Through the carrying out of these macroseismic studies, it can be seen that the macroseismic field pattern of the March 4, 1977, earthquake is similar to the macroseismic fields associated with the earthquakes of the same class of magnitude that occurred in Romania in the past (October 26, 1802; November 10, 1940) [Radu et al. 1979b, Constantin et al. 2011, Pantea and Constantin 2011]. These seismological studies show that the asymmetric spatial distribution of the major macroseismic effects that are specific to strong subcrustal Vrancea earthquakes can be explained through the convolution of the huge energy released in the seismogenic process, with the complex transfer function of the geological structures and of the crustal and subcrustal tectonic systems [Enescu et al. 1979].

An important factor that determines the distribution of macroseismic effects on territories affected by earthquakes is the type of focal mechanism, because the radiation scheme of the seismic energy is asymmetric, with the maximum slip on the fault plane and the minimum slip on the nodal plan. There are numerous observational studies that highlight the close connections between the patterns of macroseismic fields and the focal mechanisms [e.g., Enescu and Smalberger 1980]. Another factor that must be taken into account in an assessment of local macroseismic effects is the topographic factor, the influence of which can

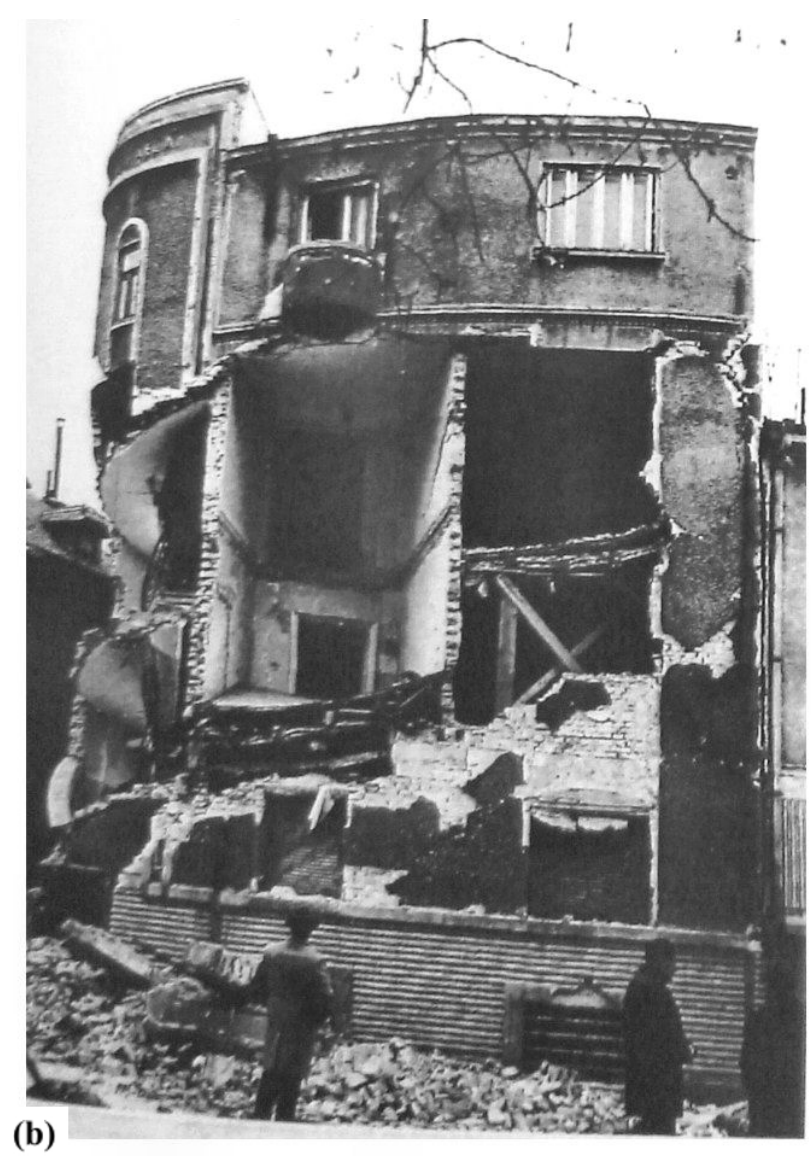

Figure 8. Partial collapse of buildings. (a) The Wilson building (reinforced concrete frame building with masonry infill walls). (b) A masonry building. (photos by Hirosawa [2007]).

often be considerable [Grünthal 1998].

In conclusion here, the determination of the new macroseismic field of this earthquake has implied a complex reanalysis and reinterpretation of the information provided by both types of investigations (macroseismic questionnaires and field surveys).

\section{Effects observed in Bucharest}

Bucharest is the capital of Romania, and it was the area that was the most affected by the 1977 earthquake, with a great number of dead and injured, and also important damage recorded. On this basis, researchers have focused their attention especially on this city, through field surveys and the use of a large number of macroseismic questionnaires (ca. 2,000 forms).

Photographs of the damage caused to the building stock that were taken after the earthquake provide important and eloquent data for the study of the effects produced by this major subcrustal earthquake. Some of the buildings severely damaged by the 1977 earthquake are shown in Figures 8 and 9 (according to the types of buildings). The most numerous and conclusive information regarding the effects on the exposed structures were obtained in Bucharest. The number and variety of the elements exposed to the seismic action of the March 4, 1977, earthquake also emphasized 


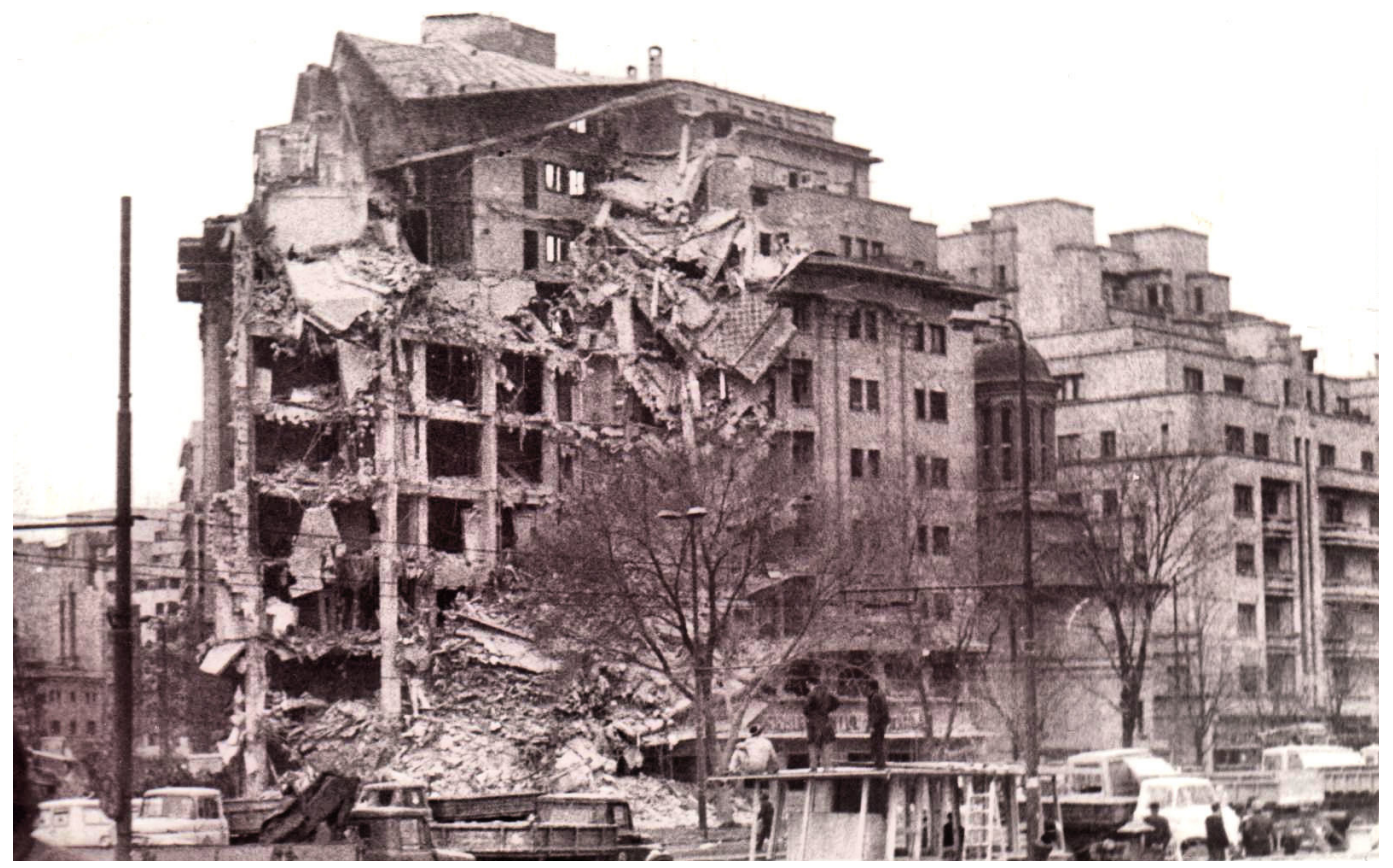

Figure 9. Partial collapse of the 'Dunarea' building (reinforced concrete frame building with masonry infill walls) (photo by Ene [1977]).

the remanent effect caused by the overloading of the resistance structures from previous earthquakes, and especially from that of the 1940 Vrancea earthquake, which thus increased their vulnerability.

When the March 4, 1977, earthquake occurred, there were two main types of buildings in Bucharest: load-bearing masonry buildings with a few storeys and wooden boards (built before 1940), and multi-storey buildings (up to 10 storeys) with reinforced concrete structures (built after 1953) [Lupan 1982]. Of the 33 collapsed buildings, 29 were high-rise reinforced concrete buildings (or reinforced concrete with brick masonry) that were built before World War II. This earthquake also caused damage to over 400 cultural institutions and over 450 hospitals. The monumental buildings affected by the earthquake included: the Telephone Palace, the Palace of Justice, the Faculty of Medicine, City Hall, the Romanian Railways Palace, the Museum of History, and many churches, schools and residential buildings [Derer et al. 2009].

Most of the buildings that collapsed during the 1977 earthquake were built before 1940, and therefore they were hit by both of the earthquakes of 1940: on October $22\left(\mathrm{M}_{\mathrm{W}}\right.$ 6.5) and on November $\left.10\left(\mathrm{M}_{\mathrm{W}}, 7.7\right)\right]$. Some of these buildings had never been repaired because of the War. However, there were also new buildings that collapsed or were seriously damaged during the 1977 earthquake (e.g., some of the buildings in the Militari, Colentina and Pantelimon districts).

Through this analysis of the information collected after the earthquake (macroseismic questionnaires, field surveys), it can be seen that the city center was the most affected, and particularly the historical part (e.g., Calea Victoriei, Blvd. Magheru, Calea Mosilor). Practically the entire old building stock of Bucharest was damaged, including the historic and high buildings that were built during the interwar period, as well as numerous palaces. In this area, the effects corresponded to an intensity of X MSK. The different values of the seismic intensity that were observed in the areas with the same types of buildings are mainly due to the geological factors; i.e., the variability of the geological structure in these areas. The final intensity obtained for Bucharest is VIII-IX MSK. In this respect, as Teves-Costa and Batlló [2011] said, it is well-known how difficult it is to assign an intensity degree to a large town where local topographical and/or geological effects can have important roles, as well as the heterogeneity in the building stock.

Due to the general socio-economical evolution typical for our era (e.g., nuclear energy, communication and development of informatics activities), there is currently rapid change in the design philosophy for resistant structures, with the appearance of new elements that can maintain the integrity of the buildings untouched.

\section{Discussion and conclusions}

The Vrancea earthquake of March 4, 1977, had a magnitude $\mathrm{M}_{\mathrm{W}}$ of 7.4, and it was the second strongest seismic event that occurred in the Romanian territory during the twentieth century, with heavy life and property losses. The strong ground motion caused severe damage, especially in the southern part of the Romanian territory. The direction of the strong movement was mostly NE-SW.

A review of the macroseismic effects produced throughout the Romanian territory by this event was the objective of the present study. After this re-evaluation, the new values obtained for the intensities are different from those previously determined. Based on our results, this seismic event was more damaging than was presented in previous studies. The 
values obtained in this study suggest an increase in the intensities observed for this 1977 Vrancea earthquake of half to one and half degrees on the MSK scale. Also, we suggest an increase in its epicenter intensity, to an $\mathrm{I}_{0}$ of IX MSK.

In the intensity data-point map of the earthquake investigated in this study, the zones defined by the macroseismic intensities of VII, VII-VIII, and VIII MSK are more extended, and they cover much larger areas than those from the map drawn by Radu et al. [1979a]. The analysis of the new map has also revealed some anomalous values of the intensities (varying from 1-2 degrees in intensity) for sites close in space that are due to the influence of the local conditions identified in the geological maps.

The results of the present study for the distribution of the re-evaluated intensities for the March 4, 1977, Vrancea earthquake, as the second largest subcrustal earthquake that occurred in Romania during the twentieth century, will contribute to the assessment of a more accurate seismic hazard for the Romanian territory, and also for the border areas, which are always affected by these powerful subcrustal earthquakes. Furthermore, the new macroseismic dataset is fundamental for improving the seismic protection of the buildings and national infrastructure (e.g., Cernavoda Nuclear Power Plant) against future major earthquakes in Romanian territory, where the risk is significant due to the high population density and the high-exposure value.

It is also necessary to make the following statement: namely, that through this re-evaluation activity, we only aimed to provide further necessary data for the antiseismic design of future civil and industrial infrastructure to ensure the safety of the population and of the natural environment, and we never wanted to discredit the work and the efforts of our predecessors through such a study, as the authors of the macroseismic map that has been re-evaluated.

Acknowledgements. The authors would like to express their thanks to the reviewers of their manuscript, for the valuable observations and recommendations.

\section{References}

Ambraseys, N.N., and R.D. Adams (1998). The Rhodes earthquake of 26 June 1926, J. Seismol., 2, 267-292.

Cecić, I., and R. Musson (2004). Macroseismic surveys in theory and practice, Nat. Haz., 31, 39-61.

Constantin, A.P., A. Pantea and R. Stoica (2011). Vrancea (Romania) subcrustal earthquakes: historical sources and macroseismic intensity assessment, Roman. J. Phys., 56, 813-826.

Derer, H., P. Derer, D. Lungu, D. Mihai and A. Pippidi (2009). Black Book: Destruction of architectural and urbanistic heritage from Romania: Bucharest, 1990-2009, 120 pp., Ed. C.N.I. Coresi, Bucharest, ISBN 978-973-570-349-3 and TUCEB-project INCO-CT-2004-509119, "Earthquake Protection of Historical Buildings by Reversible Mixed
Technologies".

De Rubeis, V., C. Gasparini and P. Tosi (1992). Determination of the macroseismic field by means of trend and multivariate analysis of questionnaire data, BSSA, 82, 1206-1222.ulletin of,

Ene, M. (1977). Images of the effects of March 4, 1977, earthquake in Bucharest, Contract 30-77-1/1977, Bucharest, 137-153.

Enescu, D., A. Pantea and V. Smalberger (1979). Synthetic Fourier spectra and accelerograms of the ground motion produced in the Bucharest area by the strong Vrancea earthquake of March 4, 1977, Studies and Research of Geology, Geophysics and Geography, Geophysics series, 17, 177-189.

Enescu, D., and V. Smalberger, (1980). Directivity functions and teoretical isoseismal lines of the strong Vrancea earthquakes, Rev. Roum. Geol. Geophys., 24, 235-254.

Grigorova, E., R. Glavtcheva and D. Sokerova (1977). The earthquake on March 4, 1977-Some results of seismic observations in Bulgaria, In: Proceedings of the Symposium on the analysis of seismicity and on seismic risk, (Liblice, Prague, 17-22 October 1977), Czechoslovak Academy of Sciences, Geophysical Institute, 109-113.

Grünthal, G., ed. (1998). European Macroseismic Scale 1998, Cahiers du Centre Européen de Géodynamique et de Seismologie, Conseil de l'Europe, Luxembourg, 99 pp.

Gutenberg, B., and C.F. Richter (1954). Seismicity of the Earth and Associated Phenomena. Princeton University Press, Princeton, N.J., 2nd ed., 310 pp.

Hirosawa, M. (2007). Photographs of building damage due to 1977 Vrancea Romania earthquake, 26th-27th April 2007, ISSRR2007, Bucharest, Romania, 26 pp.

Lupan, M. (1982). The response of different types of buildings in areas affected by earthquake, In: S. Balan, V. Cristescu and I. Cornea (eds.), The earthquake in Romania from March 4, 1977, SRR Academy Press, Bucharest, 223-346.

Mandrescu, N. (1979). The Vrancea earthquake of March 4, 1977: Damage distribution, In: I. Cornea and C. Radu (eds.), Seismological research on March 4, 1977 earthquake, Bucharest, 371-388.

Mäntyniemi, P. (2004). Pre-instrumental earthquakes in a low-seismicity region: A reinvestigation of the macroseismic data for the 16 November 1931 events in Central Finland using statistical analysis, Journal of Seismology, 8, 71-90.

Medvedev, S.V., W. Sponheuer and V. Kárník (1967). Seismic intensity scale version MSK 1964, Publ. Inst. Geodynamik, Jena, 48.

Moldovan, I.A., E. Popescu and A. Constantin (2008). Probabilistic seismic hazard assessment in Romania: Application for crustal seismic active zones, Romanian Journal of Physics, 53 (3/4), 575-591. 
Müller, G., K.P. Bonjer, H. Stockl and D. Enescu (1978). The Romanian earthquake of March 4, 1977. Rupture process inferred from fault - plane solution and multiple - event analysis, Journal of Geophysics, 44, 203-218.

Musson, R.M.W., and I. Cecić (2002). Macroseismology, In: W. Lee, P. Jennings, C. Kisslinger and H. Kanamori (eds.), International Handbook of Earthquake \& Engineering Seismology, Part A, (ISBN 10: 0-12-440652-1, ISBN 13: 978-0-12-440652-0), chapter 49.

Oncescu, M.C., V.I. Marza, M. Rizescu and M. Popa (2000). The Romanian earthquake catalogue between 984-1997, In: F. Wenzel, D. Lungu (eds.) and O. Novak (coed.), Vrancea Earthquakes: Tectonics, Hazard and Risk Mitigation, Kluwer Academic Publishers, Dordrecht, Netherlands, 43-47.

Pantea, A., N. Mandrescu, M. Popescu, E. Mihu and G. Borlea (1977). Macroseismic effects of the earthquake of March 4, 1977, CSEN Report, I, December 1977, Bucharest.

Pantea, A. (1979). Macroseismic effects of the March 4, 1977 earthquake as observed in Prahova, Dambovita and Arges districts, In: I. Cornea and C. Radu (eds.), Seismological research on March 4, 1977 earthquake, Bucharest, 615-641.

Pantea, A., and A.P. Constantin (2011). Reevaluated macroseismic map of Vrancea (Romania) earthquake occurred on November 10, 1940, Romanian Journal of Physics, 56 (3/4), 578-589.

Radu, C., G. Polonic and I. Apopei (1979a). Macroseismic field of the March 4, 1977 Vrancea earthquake, In: I. Cornea and C. Radu (eds.), Seismological research on March 4, 1977 earthquake, Bucharest, 345-357.

Radu, C., V. Kárník, G. Polonic, D. Procházková, Z. Schenková (1979b). Isoseismal map of the Vrancea earthquake of March 4, 1977, In: I. Cornea and C. Radu (eds.), Seismological research on March 4, 1977 earthquake, Bucharest, 359-369.

Radu, C., and G. Polonic (1982). Romanian territory seismicity with special reference to the Vrancea region, In: $S$. Balan, V. Cristescu and I. Cornea (eds.), The earthquake in Romania from March 4, 1977, SRR Academy Press, Bucharest, 75-136.

Radu, C., and A. Utale (1989). A new variante of the isoseismal map of March 4, 1977 Vrancea earthquake, CFPS report, no. 30.86.3/1989, Bucharest, vol. II, 31-32 (in Romanian).

Romplus catalog (2011). Updated to 2011 by the Department of Data Acquisition of the National Institute for Earth Physics (NIEP), Bucharest.

Teves-Costa, P., and J. Batlló (2011). The 23 April 1909 Benavente earthquake (Portugal): macroseismic field revision, J. Seismol, 8, 347-362.

Trita, L., V. Gavrila and N. Babalau (1978). The longest night of Craiova, Romanian Writing Publishing, Craiova, 195 pp. (in Romanian).

\section{Web sources}

NEIC (National Earthquake Information Center), http: / / earthquake.usgs.gov/ earthquakes/ world/world_deaths. php), USGS (USA).

\footnotetext{
${ }^{\star}$ Corresponding author: Angela Petruta Constantin, National Institute for Earth Physics (NIEP), Bucharest-Magurele, Romania; email: angela@infp.ro.

(C) 2013 by the Istituto Nazionale di Geofisica e Vulcanologia. All rights reserved.
} 